\title{
PENATALAKSANAAN FISIOTERAPI DENGAN MASSAGE DAN TERAPI LATIHAN PADA CERVICAL SYNDROME YANG DISEBABKAN SPONDYLOSIS
}

\author{
Giar Putri A'yuni Qolbi ${ }^{1)}$; Andrew Wijaya Saputra ${ }^{2)}$ \\ 1) giar.putri10@gmail.com, Politeknik Kesehatan Hermina \\ 2) andrew.wijaya@poltekkeshermina.ac.id, Politeknik Kesehatan Hermina
}

\begin{abstract}
Spondylosis is a degenerative disease that attacks the vertebrae, and one of the consequences of spondylosis is pain in the neck, neck pain or commonly called Cervical syndrome is a medical condition that is very common, usually appears due to a number of disorders and diseases that affect the tissues around the neck. This article aims to explain how to manage physiotherapy in cases of cervical syndrome caused by spondylosis. The type of article used is descriptive qualitative with literature-based material retrieval. The results of this study indicate that cases of cervical syndrome caused by spondylosis can be treated by physiotherapy using interventions in the form of exercise therapy and massage, this intervention aims to reduce pain and increase mobility of the neck joints.
\end{abstract}

Keywords : Spondylosis, Cervical syndrome, Physiotherapy

\begin{abstract}
Abstrak
Spondylosis merupakan penyakit degeneratif yang menyerang vertebra, dan salah satu akibat dari spondylosis adalah nyeri pada leher, nyeri leher atau biasa disebut cervical syndrome yaitu suatu kondisi medis yang sangat sering terjadi, biasanya muncul disebabkan karena sejumlah gangguan dan penyakit yang mengenai jaringan sekitar leher. Artikel ini bertujuan untuk menjelaskan tentang bagaimana penatalaksanaan fisioterapi pada kasus cervical syndrome yang disebabkan oleh spondylosis. Jenis artikel yang digunakan yaitu deskriptif kualitatif dengan pengambilan materi berbasis literature. Hasil penelitian ini menunjukan bahwa kasus cervical syndrome yang disebabkan oleh spondylosis dapat ditangani oleh fisioterapi dengan menggunakan intervensi berupa terapi latihan dan massage, intervensi ini bertujuan untuk mengurangi nyeri dan meningkatkan mobilitas sendi leher.
\end{abstract}

Kata kunci : Spondylosis, Cervical syndrome, Fisioterapi

\section{PENDAHULUAN}

Spondylosis merupakan penyakit degeneratif yang menyerang vertebra. Spondylosis disebabkan oleh proses degenerasi yang progresif pada diskus intervertebralis, yang menyebabkan osteofit, penyempitan kanalis spinalis dan foramen intervertebralis mengalami peradangan pada persendian posterior. Nyeri pada spondylosis ini disebabkan oleh terjadinya osteoarthritis dan tertekan radiks oleh kantong durameter yang mengakibatkan iskemik dan radang (Soeharso, 2005)

Nyeri leher atau biasa disebut Cervical Syndrome adalah suatu kondisi medis yang sangat sering terjadi pada umumnya, nyeri leher ini biasanya muncul disebabkan oleh sejumlah gangguan dan penyakit yang mengenai jaringan di sekitar area leher. Seperti penyakit degeneratif pada diskus, kekakuan pada leher, dan cedera leher seperti herniasi diskus (Stoppler, 2011). Tujuan penelitian adalah untuk menjelaskan tentang bagaimana penatalaksanaan fisioterapi pada kasus cervical syndrome yang disebabkan oleh spondylosis.

\section{METODE}

Metode penelitian yang digunakan yaitu deskriptif kualitatif dengan pengambilan materi berbasis literature.

\section{HASIL DAN PEMBAHASAN Etiologi}

Nyeri pada leher dapat disebabkan oleh beberapa faktor, antara lain faktor musculoskeletal, faktor nervorum, faktor vascularisasi, dan faktor pada persendian (Hudaya, 2009). Berikut merupakan faktor penyebab dari cervical syndrome meliputi : 


\section{Indonesian Journal of Health Science}

Volume 1 No. 1, Juni 2021

a. Trauma

Trauma bisa disebabkan oleh kecelakaan lalu lintas yang mengakibatkan whiplash injury, bisa juga karena kecelakaan kerja atau olahraga yang bersentuhan langsung dengan tubuh sehingga menimbulkan adanya nyeri pada area leher. Beberapa pekerjaan yang menyebabkan timbulnya trauma misalnya pada tukang cat plafon, tukang potong rambut, dan seorang pekerja kantor yang selalu bekerja di depan laptop (Hudaya, 2009).

b. Kesalahan Postural

Keterbiasaan sikap dengan postural dan posisi yang salah dan terlalu lama dapat menyebabkan nyeri pada leher, misalnya tidur menggunakan bantal yang terlalu tinggi dan menggerakan leher secara tidak sengaja.

c. Penyakit degeneratif

Adalah suatu kondisi yang kebanyakan menyerang area leher pada usia dewasa yang kemudian semakin lama seiring bertambahnya usia kondisinya semakin meningkat sehingga mengakibatkan rasa sakit pada leher, kondisi seperti ini dinamakan dengan spondylosis cervicalis yang tampak dari pemeriksaan radiologis yaitu : berubahnya diskus intervertebralis, terbentuknya osteofit pada paravertebral dan perubahan pada arcus lamina area belakang dan facet joint.

\section{Insiden dan Prevalensi}

Menurut penelitian sekitar 20\%-70\% menunjukan bahwa populasi manusia pernah mengalami nyeri leher sekali seumur hidup. Ditambah lagi insidensi nyeri leher meningkat oleh karena usia dan umumnya yang cervical syndrome paling sering terjadi yaitu pada wanita usia sekitar 50 tahun keatas (Childs, J.D, 2008).

Kasus di Indonesia, setiap tahun prevalensi nya sekitar 16,6\% populasi orang dewasa mengeluhkan rasa sakit di leher, bahkan $0,6 \%$ pada awalnya dari rasa tidak enak di leher menjadi nyeri leher yang sangat berat. Lalu Insidensi nyeri leher meningkat dengan bertambahnya usia, dimana wanita lebih sering terkena daripada laki-laki dengan perbandingan 1,67:1 (Hudaya, 2009).

\section{Manifestasi Klinis}

Manisfestasi klinis yang muncul pada kasus cervical syndrome meliputi:

a. Gejala nyeri pada area leher yang bersifat terus-menerus, nyeri itu muncul seperti nyeri tekan pada otot-otot diarea leher, area scapula dan area bahu. Otot-ototnya meliputi otot SCM, otot levator scapulae, otot ekstensor cervical, otot upper trapezius, otot rhomboid major dan rhomboid minor. Kemudian nyeri gerak pada area leher jika digerakan seperti gerak fleksi, ekstensi, lateral fleksi dan rotasi kanan dan kiri baik gerak aktif maupun pasif.

b. Adanya spasme otot leher, scapula dan pundak pada otot SCM, levator scapulae, ekstensor cervical, upper trapezius, rhomboid major dan rhomboid minor.

c. Adanya keterbatasan gerak pada area leher yang meliputi gerakan fleksi, ekstensi, rotasi kanan dan kiri, lateral fleksi kanan dan kiri terbatas untuk melakukan gerakan aktif ataupun pasif.

d. Gangguan postural ini disebabkan karena penderita sering melakukan gerakan kompensasi untuk menghindari munculnya rasa nyeri, sehingga menyebabkan bahu menjadi asimetris atau bahu tidak tegak.

\section{Tingkat dan Proses Penyakit}

Patofisiologi cervical syndrome tidak adanya kondisi traumatic seperti fraktur, dislokasi maupun subluksasi namun hal ini bisa disebabkan karena spondilosis cervical. Kondisi ini yang menimbulkan kaku kuduk (neck stiffness) atau suatu rasa nyeri yang muncul karena capsule sendi yang mengandung serabut saraf yang sensitif terhadap peregangan dan distrosi, selain itu ligament dan tendon di leher sensitif terhadap regangan dan torsi yang disebabkan karena 


\section{Indonesian Journal of Health Science}

Volume 1 No. 1, Juni 2021

gerakan yang terlalu keras atau gerakan yang terlalu berlebihan pada leher atau bagian punggung atas, dan juga karena osteofit bisa memberi tekanan pada akar saraf atau medulla spinalis karena foramen intervertebral menyempit akibat membesarnya osteofit paravetebra dan facet joint. Jika ukuran lubang foramen intervetebra mulai menyusut secara perlahan, kondisi tersebut membutuhkan strain cervical yang ringan saja sudah dapat menyebabkan gejala radikuler yaitu berupa rasa sakit atau rasa kesemutan yang menyebar dari area lateral leher, lalu turun ke area bahu, lengan dan pergelangan tangan, kondisi ini tergantung dari akar saraf mana yang mengalami penekanan (Hudaya, 2009).

\section{Pemeriksaan dan Pengukuran}

\section{Pemeriksaan Inspeksi}

Pemeriksaan Inspeksi yaitu pemeriksaan yang dapat dilihat dari fisik, pada kasus cervical syndrome yang disebabkan oleh spondylosis setelah diinspeksi terdapat adanya tanda-tanda inflamasi seperti nyeri, kemerahan, bengkak, suhu yang panas, dan keterbatasan fungsional.

2. Pemeriksaan Palpasi

Pemeriksaan Palpasi yaitu pemeriksaan dengan mempalpasi bagian yang sakit, pada saat pemeriksaan palpasi pada kasus ini ketika di palpasi terdapat adanya pembengkakan di area leher dan juga terdapat kekakuan pada area cevical.

3. Pemeriksaan sensory

Pemeriksaan ini berguna untuk melihat sensory pasien apakah pasien masih bisa merasakan stimulus sensory jika diberi sensory di area yang sakit contohnya sensory panas dan dingin, tajam dan tumpul, kasar dan halus.

4. Pengukuran derajat nyeri

Pengukuran derajat nyeri dengan VAS (Visual Analog Scale) dengan ketentuan angka 1-10, angka 1 menunjukan nyeri sangat ringan, angka 5 nyeri sedang dan angka 10 nyeri sangat berat.

5. Pemeriksaan gerak aktif dan pasif

Pemeriksaan ini berguna untuk melihat apakah ada keterbatasan ROM pada saat menggerakan fleksi, ekstensi, lateral fleksi dan rotasi cervical. Pada pasien cervical syndrome yang disebabkan oleh spondylosis pasien memiliki keterbatasan ROM pada saat menggerakan gerak aktif dan pasif karena adanya nyeri.

\section{Intervensi Fisioterapi}

Fisioterapi yang merupakan salah satu cabang dari ilmu kesehatan, sangat berperan dalam upaya peningkatan kesehatan dengan memberikan pelayanan kesehatan. Pelayanan fisioterapi berupa pelayanan yang diberikan kepada individu dan masyarakat dalam upaya memelihara, memperbaiki gerak dan fungsi tubuh manusia. Oleh karena itu peran serta masyarakat sangat diperlukan dalam rangka menciptakan upaya kesehatan yang bermutu (Priatna, 2001). berupa :

Modalitas yang digunakan pada kasus Cervical Syndrome akibat spondylosis cervicalis

\section{Terapi Latihan}

Terapi latihan berguna untuk meredakan nyeri pada leher dan mengurangi kekakuan pada otot leher. Terapi Latihan ini terdiri dari tujuh gerakan (sesuai dengan keadaan pasien) dan dilaksanakan sampai batas ROM atau sampai pasien merasakan nyeri, latihan ini berupa gerakan aktif sehingga hal ini menimbulkan terjadinya kontraksi otot-otot leher yang kemudian diikuti relaksasi sehingga akan merangsang Mekanoreseptor sehingga menimbulkan dinding kapiler yang terdapat pada otot membesar dan permeabilitas dinding kapiler menjadi meningkat. Kondisi ini yang akan mempengaruhi relaksasi otot, meredakan rasa nyeri, mengurangi kekakuan otot, dan melancarkan sirkulasi darah (Mc Kenzie, 2000). 


\section{Indonesian Journal of Health Science}

Volume 1 No. 1, Juni 2021

\section{Massage}

Massage dalam kondisi ini berguna untuk meminimalisasi rasa nyeri dan juga berguna untuk meningkatkan ROM. Proses yang terjadi pada saat di massage berupa mekanik (penataan kembali serat otot), neurologis (gate control theory), dan juga fisiologis (zat biokimia). Massage dapat meminimalisasi rasa nyeri dengan cara massage mengaktifkan mekanisme saraf di vertebra. Informasi taktil yang diberikan oleh massage dapat merangsang saraf berpenampang tebal yang kemudian memblokir saraf yang berpenampang tipis sehingga mendeteksi rasa nyeri. kondisi ini mengakibatkan adanya penghambatan tingkat local di sumsum tulang belakang dan massage sendiri juga dapat meningkatkan zat biokimia seperti serotonin, yang merupakan neurotransmitter yang juga berperan dalam menghilangkan rasa sakit (Weerapong, P, 2005).

Dengan diberikan massage ini dapat membantu untuk mengatur ulang serat otot dan melancarkan sirkulasi darah. Dan jika penataan ulang serat otot bisa membantu kekakuan otot yang merangsang reseptor rasa nyeri sehingga jika kekakuan otot berkurang hal ini dapat meningkatkan ROM pada area cervical (Weerapong, P, 2005).

\section{PENUTUP}

\section{Simpulan}

Berdasarkan pemaparan di atas, dapat disimpulkan bahwa pada kasus cervical syndrome akibat spondylosis cervicalis yang disebabkan oleh adanya beberapa faktor seperti trauma, kesalahan postur dan penyakit degeneratif. Masalah tersebut dapat ditangani dengan menggunakan intervensi fisioterapi berupa terapi latihan dan massage yang bermanfaat untuk mengatasi masalah yang terjadi seperti meminimalisasi rasa nyeri, meningkatkan ROM ketika melakukan gerakan di leher.

\section{Saran}

Intervensi yang dilakukan oleh fisioterapi dapat memberikan hasil yang optimal jika dilakukan dengan intensitas terapi yang tepat dan teknik penanganan yang benar, dan juga tidak hanya dari fisioterapi saja penanganan ini juga bisa dilakukan secara homeprogram secara rutin namun sesuai dengan arahan dari fisioterapi hal ini bertujuan agar penderita bisa segera pulih dari sakitnya dan bisa beraktifitas seperti biasa tanpa adanya keluhan.

\section{DAFTAR PUSTAKA}

Childs, J.D, e. (2008). Neck pai: Clinical Practice Guidelines. Journal of Orthopaedic and Sports Physical Therapy, American.

Hudaya, P. (2009). Patofisiologi Nyeri Leher. disampaikan dalam seminar nasional pendidikan kesehatan manajemen nyeri cervical dan shoulder.

Mc Kenzie, R. (2000). 7 Steps To A Pain Free Life; Dutton,. United States Of America, Hal.227-243.

Priatna, H. (2001). Pengantar Kuliah Fisioterapi . Surakarta: Akademi Fisioterapi Surakarta.

Soeharso, H. d. (2005). Nyeri Punggung Bawah (Harsono). Yogyakarta: Gadjah mada university press.

Stoppler, M. (2011). Neck Pain. Diakses pada tanggal 26 September 2021, dari http://www.medicinenet.com/neck_pain/article.htm

Weerapong, P, H. K. (2005). The mechanisms of massage and effect on performance, muscle recovery and injury prevention. New Zealand: Auckland University of Technology. 